\title{
Constraints under organic farming on French sheepmeat production: a legal and economic point of view with an emphasis on farming systems and veterinary aspects
}

\author{
Marc BENOIT*, Gabriel LAIGNEL \\ Laboratoire d'Économie de l'Élevage, INRA Clermont-Ferrand Theix, \\ 63122 Saint Genès-Champanelle, France
}

(Received 13 November 2001; accepted 18 March 2002)

\begin{abstract}
Ovine meat production in France, which is continually regressing due to economic difficulties, is based on two main production systems. The first system is located in plains in which one part of the lambs born in the spring are fed grass, and the other part of the lambs are from out of the season parturitions following hormonal treatments and are fattened in sheep houses. The second system is represented by farms in the mountains using hardy breeds which have a natural faculty for out of the season breeding and whose lambs are fattened indoors, whatever the season of birth. Amongst the sanitary problems encountered, parasitism in particular of young animals, is crucial, especially for farms on plains practising grass fattening. These farmers systematically use conventional anthelmintic treatments, in particular against Moniezia and Strongyles. With organic farming, the limited number of conventional anthelmintic treatments is a strong constraint, especially for the management of young grass-fed animals. A study of 10 organic farming farms or farms converting to organic farming (six in the mountains and four in the plains) showed that the size of these farms is inferior to that of conventional ones and have technical performances which are comparable to the average with 20 to $30 \%$ extra over-prices on lamb sales. Despite this, the gross margins per ewe in organic farming are equal to the average of those for conventional farms. This is due to the high consumption of concentrate at a high cost (50 to $100 \%$ greater than that for conventional farms). Finally, to prevent sanitary risks, certain organic farmers use important amounts of feed supplements containing phytotherapy products whose costs burden a part of the financial results of the farm. On the contrary, other organic farmers are able, by adapting breeding and grazing managements, to significantly decrease animal health costs without increasing feed supplements nor decreasing zootechnical performances.
\end{abstract}

sheepmeat / organic farming / economics / health / France

*Correspondence and reprints

Tel.: (33) 4736241 34; fax: (33) 4736245 18; e-mail: marc.benoit@clermont.inra.fr 
Résumé - Les contraintes en production ovine allaitante biologique en France : cadre réglementaire et économique, fonctionnement des systèmes et aspects sanitaires. La production ovine française, dont l'effectif de brebis est en constante régression du fait de difficultés économiques, est basée sur deux principaux systèmes de production: celui des zones de plaine, dont une partie des agneaux, nés au printemps, est engraissée à l'herbe, l'autre partie, issue de mise bas de contre-saison avec traitements hormonaux, étant engraissée en bergerie. L'autre système est celui représenté par les exploitations de montagne utilisant des races dites rustiques, ayant une faculté naturelle de reproduction en contre-saison et dont les agneaux sont engraissés en bergerie, quelle que soit la saison de naissance.

Parmi les problèmes sanitaires rencontrés, le parasitisme, particulièrement celui des jeunes animaux, est crucial, en particulier dans les élevages de plaines pratiquant l'engraissement à l'herbe. Ceux-ci utilisent de façon systématique des traitements allopathiques à base de produits de synthèse, en particulier contre les Moniezia et les Strongles. En exploitation en agriculture biologique (AB), la limitation du nombre de traitements à base de produits de synthèse est donc une contrainte forte, en particulier pour la conduite des animaux jeunes à l'herbe. L'étude de 10 exploitations en agriculture biologique ou en conversion (six en montagne et quatre en plaine) montre que ces exploitations ont des tailles inférieures aux conventionnelles, qu'elles ont des performances techniques comparables à la moyenne avec des plus values de prix sur les ventes d'agneaux de 20 à $30 \%$. Malgré cela, les marges par brebis sont dans la moyenne des exploitations conventionnelles du fait du maintien des consommations de concentrés dont le prix d'achat est supérieur de 50 à $100 \%$ au conventionnel. Afin de prévenir les risques sanitaire, certains éleveurs en $\mathrm{AB}$ utilisent de façon très importante des suppléments alimentaires le plus souvent à base de phytothérapie dont le coût obère une partie du résultat d'exploitation. A l'opposé, d'autres éleveurs en $\mathrm{AB}$ ont pu, en adaptant la conduite d'élevage et en particulier celle du pâturage, diminuer significativement les frais concernant la santé des animaux, sans pour autant augmenter les suppléments alimentaires ni voir les performances zootechniques chuter.

production ovine / agriculture biologique / économie / santé / France

Table of contents

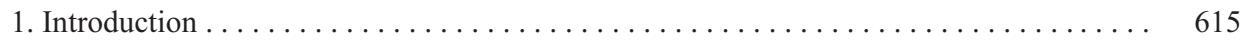

2. Constraints and consequences to organic farming production $\ldots \ldots \ldots \ldots \ldots \ldots \ldots$

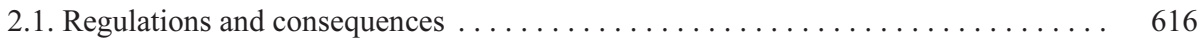

2.1.1. Concentrate proportions limited to $30-40 \%$ of the daily ration . . . . . . . 617

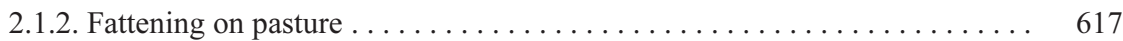

2.1.3. Limitation of the number of anthelmintic treatments. . . . . . . . . . 617

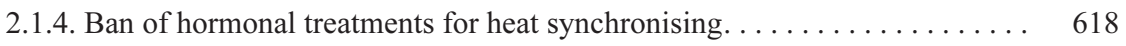

2.2. The ovine species as the prototype of a breeding production study in organic farming. . $\quad 618$

3. Sheepmeat farming observations: specificities of organic farms vs. conventional farms . 618

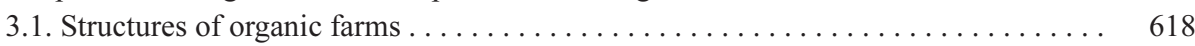

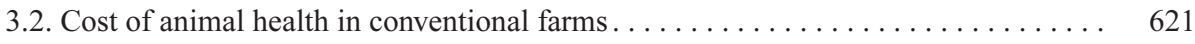

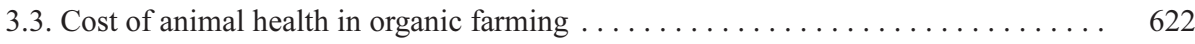

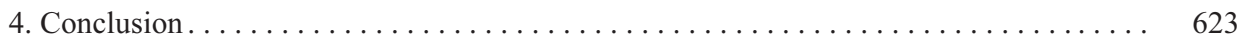




\section{INTRODUCTION}

The size of the French ovine population, representing $10 \%$ of the 15 European countries' population, has been continually decreasing at a rate of about $1 \%$ per year since 1981 , the year in which the common organisation of the sheepmeat market began (Fig. 1). The number of mated ewes reached 7.3 millions in 2000 [1], as compared to 9.7 millions in 1981, the decrease being imputable to sheep for meat which represents $78 \%$ of all in 2000 .

This erosion of the population is regular and does not show any signs of slowing down even though the total European population has remained stable for the past few years. This evolution hides the restructuring of the farms, with small flocks vanishing to the profit of flocks with over 350 ewes. In fact, the geographic distribution of the population is unequal, with $85 \%$ of the ewes belonging to farms which are located in zones at a disadvantage (difficult natural conditions in relation with altitude, climate and soil). The general tendency is the progressive disappearance of sheep in plain zones (and even in intermediary zones), under the pressure of arable crop systems and to a lesser extent, the production of beef cattle. This decrease in the
French population of sheep for meat is due on the one hand to its low profitability and on the other hand, to the important amount of work with this type of breeding in the French context.

In 1999, the income of a worker on a French sheepmeat farm only reached $50 \%$ of the national average, that is $8600 €$ as compared to $17000 €$. The farms located in zones at a disadvantage had the most difficulty, with $6700 €$ and $7500 €$ in the zones of intermediate $(300-600 \mathrm{~m})$ and high $(>600 \mathrm{~m})$ altitudes, respectively, as compared to $11600 €$ in plain zones [3].

This type of breeding cannot be mechanised, on the contrary to arable crop systems. In addition, this type of breeding is confronted with competition for land from other productions (animal and plant). For this reason, the available surfaces are only rarely managed in an extensive manner, except in dry zones. These limited surfaces determine the flock size which should be managed with a minimum level of zootechnical intensification to ensure a minimum level of economic profitability. In fact the correlation coefficients between the gross margin per ewe and the income for specialised sheepmeat farms, and between the numeric productivity (number of lambs weaned per ewe and per year) and the gross

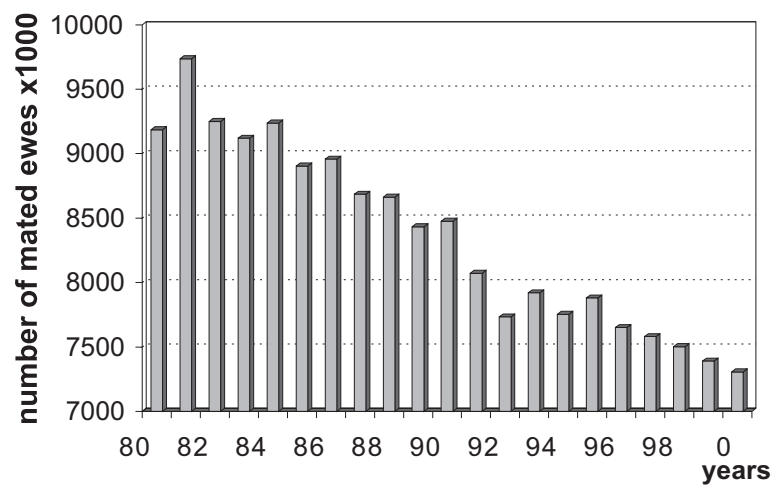

Figure 1. Evolution of the number of mated ewes (1000 animals) between 1980 and 2000. France [1]. 
margin per ewe are high [2]. Average to high ( $>1.4)$ productivity levels are obtained by a good mastering of three essential factors: prolificacy, death of lambs, and rate of lambing (associated with fertility). In order for good results to be obtained, each ewe must be closely (and individually) followed with frequent interventions on the flock. Good zootechnical performances, which are obtained with 300 ewes, are much more difficult to obtain with 500 or 700 ewes, which is the recommended average size of flocks today in mountainous and plain zones.

National production of sheepmeat is deficient; the rate of self-provisioning (production/consumption) fell to $39 \%$ in 1999 . Competition has always been strong with the United Kingdom that furnishes half of the tonnage that is imported into France. Important importation contingencies with total exoneration of duty have been granted to 5 countries of the southern hemisphere, including 220000 tons from New Zealand without a quota for cut meat ("chilled"), refrigerated meat under a controlled atmosphere, and long conservation. This meat enters directly into competition with European meat production and more particularly French production during the winter.

For this reason a double strategy has been adopted by French sheepmeat producers:

(i) Important efforts have been done to increase out of season production in order to differentiate French sheepmeat production from that imported and to consolidate partnership with the sector. In the Poitou-Charentes region, the number one producer of sheepmeat in France, observations have shown that $1 / 3$ of lambings now occur out of season (October to December), with grass-land breeds having received hormonal treatments (Vendéen, Texel sheep, ...). On a national level, this production comes to comfort (or enter into competition with?) lamb production from more rustic mountainous breeds which are less sensitive to seasonal anoestrus. These lambs are fattened in sheep houses with 60 to $70 \mathrm{~kg}$ of concentrate and are slaughtered at 16.5 to $18 \mathrm{~kg}$ carcass weight.

(ii) Development of traceability and official sign of quality: for example, in 2000, the major marketing cooperative of the Massif Central commercialised $47 \%$ of its lambs under four distinct quality criteria (Certificats de Conformité du Produit). However, the guarantees of traceability of the lambs, the conformity of the specifications and the necessary spreading of the production over the year has demanded much efforts from the farms in terms of a calendar of ewe mating, selection of the animals, and accompanying documents.

Due to such politics which tend to be generalising throughout France, at certain periods of the year, the quotation of French meat has reached a superior level of $1.5 € / \mathrm{kg}$ of that of imported meat.

Ovine production in organic farming is an integral part of these production policies under strict criteria of quality. It has been steadily growing $(+50 \%$ between 1998 and 1999) but remains a minority as does most organic produce in French agriculture (1.3\% in 2000).

\section{CONSTRAINTS AND CONSEQUENCES TO ORGANIC FARMING PRODUCTION}

\subsection{Regulations and consequences}

Since August 24, 2000, French organic farmers have had to follow the specifications put forth by the European regulations for Organic Animal Productions (Règlement Européen des Productions Animales Biologique (REPAB)), complemented by French regulations (REPAB-F) [8].

More specifically, the following four points of these regulations cause specific constraints for sheepmeat farms. 


\subsubsection{Concentrate proportions limited to $30-40 \%$ of the daily ration}

On mountainous sheep farms (and in plains in the winter), feed for fattened lambs is usually based on roughage (hay) and concentrates which are distributed ad libitum. These concentrates can thus be estimated at about $70 \%$ of the daily ration.

The limitation of concentrates in the ration to $40 \%$ for fattened lambs has two essential implications:

- to privilege the distribution of a fodder of excellent quality;

- later weaning of the lambs in order to maximise the milk part in the diet;

- such management should lead to lower daily growth of the lambs, longer fattening periods, potentially higher carcass weights of the lambs, and to the maintenance and even a slight decrease of the overall quantities of concentrates used.

The limitation of concentrate use for ewe feeding in the winter (essentially hardy breeds) at the end of gestation (limited capacity of ingestion) and at the beginning of lactation following multiple births, can also be a technical constraint and lead to eventual sanitary consequences. There again, roughage of excellent quality must be used, including haylage (within the authorised limit of $50 \%$ of dry matter of the ration).

\subsubsection{Fattening on pastures}

Lambs which are in the fattening stage should not spend more that one-fifth of their life indoors and in any case less than three months, except if the pedoclimatic conditions prevent them from going outdoors.

This constraint especially concerns mountainous lambs who are born early in the spring and for whom, even if they can go out with their mothers during lactation, it is very difficult to fatten outside due to:

- a very high irregularity in grass growth during the summer (pedoclimatic context);
- a very limited availability of fodder resources;

- difficulty controlling parasitism;

- dispersion of land (parcelling) and important distances of the buildings for breeding;

- strong thermic contrasts in the region (continental climate);

- the absence of this type of fattening practices by farmers and the habitual request by the conventional sector for young lambs with rapid growth.

More generally, the control of parasitism of grazing lambs continues to be one of the most preoccupying problems in organic farming with the following consequences:

- illness or death of lambs;

- growth retardation which could have negative economic consequences due to the overconsumption of food;

- possible degradation of the quality of the carcasses produced, especially concerning the quality of the fat for lambs with slow growth [11].

\subsubsection{Limitation of the number of anthelmintic treatments}

For adults, this number is limited to two for the products other than antiparasitic compounds and to two for antiparasitic products (three if an ectoparasitic treatment is needed) with an overall maximum of three treatments, over a period of 12 months. For lambs, these numbers are respectively one (not antiparasitic), three (antiparasitic) and three overall. The use of controlled-release medicine (bolus) is prohibited.

This aspect of the regulations, essentially causes a problem for the fattening of grassland lambs for which, in conventional breeding, the number of treatments is usually greater than three.

This imposes, on the one hand, that lambs graze as much as possible on uncontaminated pastures, and on the other hand to 
identify alternative possibilities to conventional anthelmintic treatment (phytotherapy, ...) [5]. Methods using individual observations of the animals, however, allow for treatments to be targeted [12]. Upon an eventual third treatment, the farmers may systematically fatten sheep in sheep houses so that they will not have to use a fourth treatment which is not allowed for organic farming, but indoor fattening period should not exceed one-fifth of the lamb's life and should last less than three months.

\subsubsection{Ban of hormonal treatments for heat synchronising}

Under the pressure of the sector and of some consumers of organic products, breeders are looking for ways to produce out of season lambs, that is lambs with births from September to December that can be commercialised from January to April. Hardy breeds have, to different degrees, the capacity to reproduce out of season. On the contrary, this type of breeding is not possible with ordinary plain breeds. Besides the choice of certain genotypes adapted to out of season reproduction, some methods which help advance the reproducing season (ram effect in particular) can be used in organic farming.

\subsection{The ovine species as the prototype of a breeding production study in organic farming}

Organic farming has been presented as a prototype for the study of system adaptation under strong constraints. This could also be the same for sheep, which could be considered as a prototype for the study of the adaptation of breeding systems to organic farming. Indeed, numerous phenomena seem to be exacerbated for this species:

- a short gestation time (compared to cattle) that can allow, under certain contexts, a rapid rhythm of reproduction (in particular, reproduction systems with three parturitions over a two year period);

- prolificacy that varies according to breed from 100 to $200 \%$ and more;

- very high growth levels of the litters, as compared to mother weight (average daily growth of the litter reaching $1 \%$ of the mother's weight); weight of the lambs at six months reaching $60 \%$ of adult weight as compared to $45 \%$ for cattle;

- the animals could be raised in intensive or very extensive systems (rangelands and dry zones);

- in partial relation with this production potential, a strong sensibility to feeding errors, to mineral deficits and often, at least in conventional systems, to parasites.

\section{SHEEPMEAT FARMING OBSERVATIONS: SPECIFICITIES OF ORGANIC FARMS VS. CONVENTIONAL FARMS}

\subsection{Structures of organic farms}

Technical-economic investigations were performed on farms over a long period from 1987 to 2000 [2]. Their objective was to identify the main factors (technical and economic) of profitability of farms by studying 49 farms situated in plain zones $(n=26)$ and mountainous zones $(n=23)$; six were organic farms (three in each region) and four were farms in conversion to organic farming (Figs. 2 to 7 ).

As the four types of monitored farms (plain, mountain, conventional or on organic farming), are heterogeneous, (localisation, size, specialisation on sheep production), especially regarding organic farms, and comprised a few farms, we will not pretend to statistical inference. We will only discuss on the reasons of some apparent differences between organic and conventional farms. 


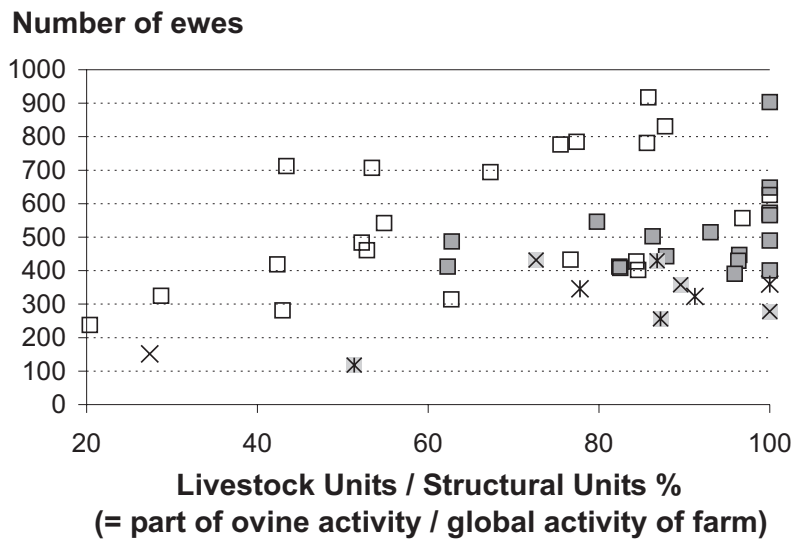

Figure 2. Number of ewes and farm specialisation on sheep production.

Structural Units $=$ Livestock Units $(1$ ewe $=0.14 \mathrm{LU}, 1 \mathrm{lamb}=0.05 \mathrm{LU})+$ hectares of cereals and cultures + equivalent units for others farm activities (= gross margin/sheep gross margin per LU). White: plain; grey: mountain; $*$ : organic; $\mathrm{x}$ : convers. to org.

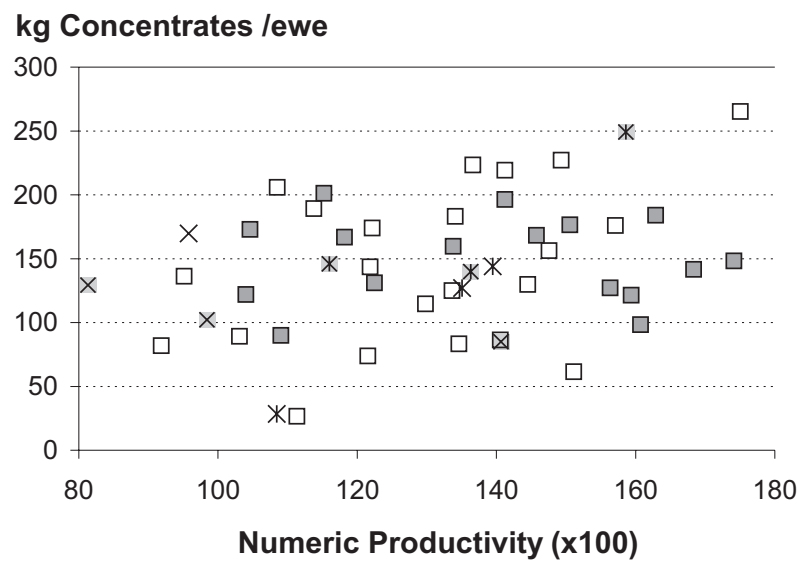

Figure 3. kg of food concentrates per ewe and numeric productivity (number of lambs weaned per ewe and per year).

White: plain; grey: mountain; $*$ : organic; $\times$ : convers. to org.

If we consider all the farms studied (Fig. 2), the size of the farms in plains are on the average larger than those in the mountains, often made up of flocks of 700 ewes and sale cultures representing $50 \%$ and more of the farms' activities. In the mountains, the farms are more specialised (ovine activity is greater than $60 \%$ of the total activities) and it is rare for flocks to have more than 600 ewes. The organic farms or farms in transition to organic farming have smaller sizes, between 250 to 420 ewes for those that are the more specialised.

Generally, the profitability of the ovine activity is essentially founded on combining two basic criteria: the level of numeric productivity (number of lambs weaned per 


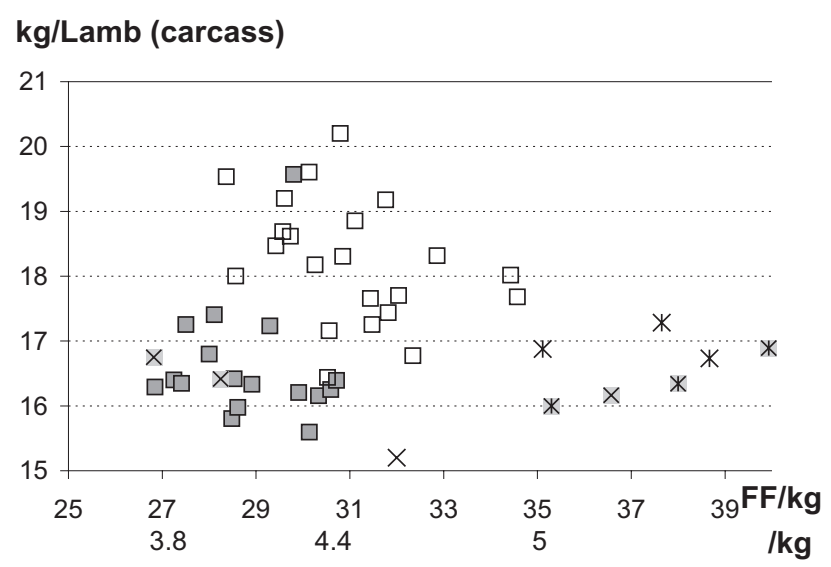

Figure 4. Carcass weight and price of the lambs. White: plain; grey: mountain; $*$ : organic; $\times$ : convers. to org.

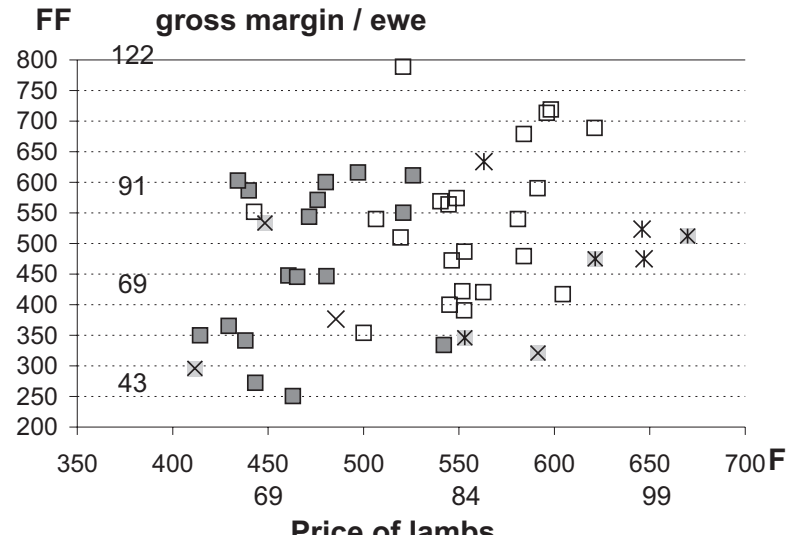

Figure 5. Gross margin per ewe and selling price of the lambs. White: plain; grey: mountain; $*$ : organic; $\times$ : convers. to org.

ewe and per year) and concentrate ingestion (Fig. 3). These criteria are extremely variable between farms, particularly in plain zones where the numeric productivity varies from 0.90 to 1.80 and the consumption of concentrates varies from 25 to $265 \mathrm{~kg}$ per ewe (including lambs) and per year. This is the translation of the diversity of the production systems (system of out of season breeding with lambs indoors and the grassland system with parturition in the spring and grass-fed lambs) and of the various mastering of the breeding technique. For organic or converting farms, the numeric productivity remains very heterogeneous, but, in half of the cases, it is greater than 1.35; the consumption of concentrates is often situated between 100 and $150 \mathrm{~kg}$ per ewe. Due to their costs, such levels of consumption, which are conform to conventional farms, have a very high incidence on the gross margin per ewe. Indeed, despite these levels of productivity and an excellent valorisation of the lambs (Fig. 4: +20 to 


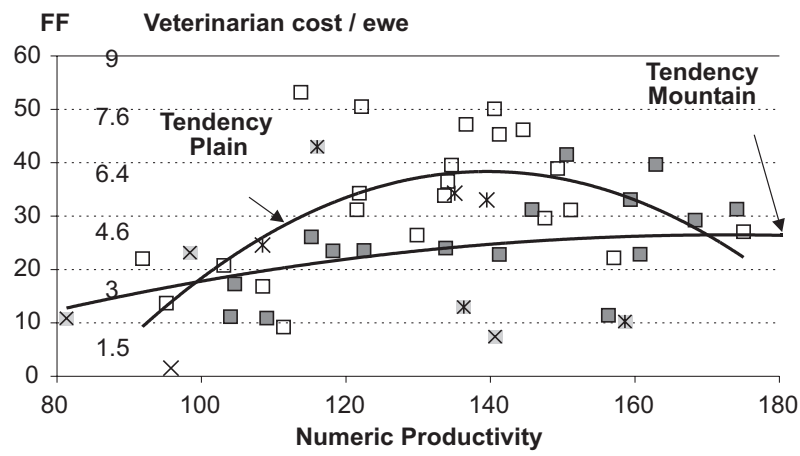

Figure 6. Veterinary costs per ewe and numeric productivity (second order polynomials fit) for plain and mountain farms. White: plain; grey: mountain; $*$ : organic; $\times$ : convers. to org.

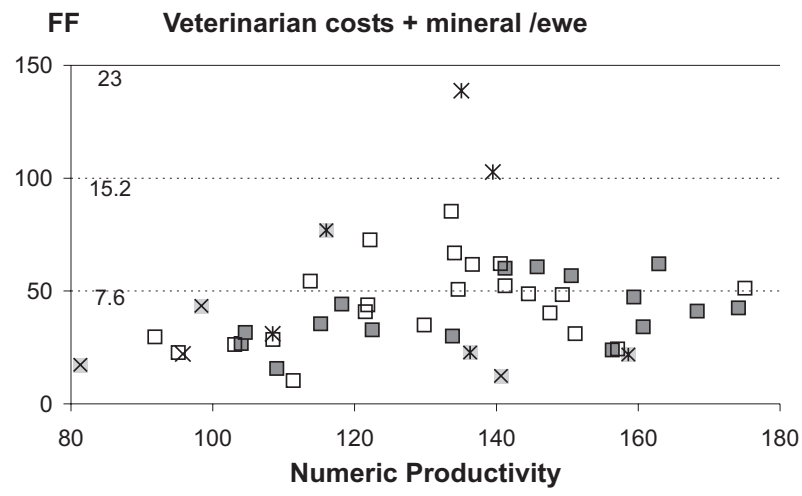

Figure 7. Veterinary costs, mineral supplementation, vitamins per ewe and numeric productivity. White: plain; grey: mountain; $*$ : organic; $\times$ : convers. to org.

$+30 \%$ of the selling price per kilo, for lambs that can be compared), the gross margin per ewe exceptionally goes over $91 €$, with an average of $76 €$ (Fig. 5).

This final average performance is directly associated with the price of the concentrates, between 50 and 100\% greater than that of conventional concentrates. These studies show that in order to improve the profitability of organic farms, fodder self-sufficiency must first be improved, that is roughage (grazing or harvested) in the flock feed. This means that, especially for mountainous farms that have not been fattening lambs with grass for decades, a good mastering of parasitism with a minimum number of conventional anthelmintic treatments.

\subsection{Cost of animal health in conventional farms}

On the average, the veterinarian costs reach, for mountainous farms, $3.5 €$ /ewe, that is $7 \%$ of ovine costs and $5 \%$ of the gross margin per ewe $(71 €)$. On farms in plains, the average level is higher, $5 € /$ ewe, that is $12 \%$ of the ovine costs and $6 \%$ of the gross margin per ewe ( $83 €$ ). The costs concerning animal health are far from the costs of 
feeding (these ones represent $60 \%$ of the total breeding costs) but, according to the purpose of the paper, we detail them.

The difference of the costs of animal health between mountainous farms and those in plains can be explained by the way the lambs are fattened: they are systematically fattened indoors in the mountains, without any antiparasitic treatment, to be sold anywhere from 70 days of age (small lambs with $24 \mathrm{~kg}$ live weight; $25 \%$ of lambs) to 120 days (heavy lambs for meat, slaughtered at $16.5 \mathrm{~kg}$ carcass weight). On plains, $38 \%$ of the lambs are raised indoors, $16 \%$ are fattened with grass then finished indoors, $31 \%$ are fattened with grass with additional concentrates and only $9 \%$ are strictly fattened with grass; the lambs still grazing after weaning receive an antiparasitic treatment every 1 to 1.5 months [7]. The main parasites are Moniezia and Strongyles [6].

Since the investigations that were carried forth were not specifically intended to study animal health, the health costs were grouped together, even if they concerned veterinary costs, analyses, and, for the large majority, veterinary products including antiparasitic products. The cost of short-time employment amid the veterinary costs is very low; veterinarians only rarely come to the farms except for prophylaxis or for major sanitary problems The mineral, vitamins and diverse nutritional supplements (including phytotherapy) were regrouped in a particular position but the distinction between these products and other veterinary products is often difficult in organic farming.

The major sanitary problems concerning sheep raised in sheep houses is Coccidiosis and Strongyles [9]. Moniezia and digestive Strongyles are very frequent [4], and are systematically treated for grassland lambs.

In the mountains, there is a certain connection between the level of numeric productivity and the "veterinary costs" (Fig. 6). In plains, the veterinary costs are higher for those farms whose productivity is between 1.20 and 1.40 , with a significant part of the lambs fattened with grass. The veterinary costs for these lambs are in fact greater than those of lambs in sheep houses that have never been treated for Moniezia and Strongyles. Beyond these levels of productivity (1.20-1.40), are mainly farms having a significant number of out of season parturitions with fattening of lambs in sheep houses.

\subsection{Cost of animal health in organic farming}

With regards to the zootechnical observations realised and the recorded performances, we may consider that organic farmers encounter few problems and/or have found technical means that help them be resolved with the authorised means. We have however studied the veterinary costs and feed supplements (phytotherapy in particular) (Fig. 7), which are the most often used for prevention.

Whereas for conventional farms (mountainous or plains) the cost of animal health is $6 €( \pm 3 €)$ per ewe, two out of six breeders in organic farming had costs which were greater than $15 €$ per ewe in 2000 , nearly reaching $21 € /$ ewe each year, which represents $30 \%$ of the gross margin of the ovine activity, that is about half of the income. On the contrary, several organic farmers or farmers in transition to organic farming, obtaining good zootechnical performances, have costs that are less than $3.8 €$ /ewe, which is one of the lowest of the above observations. This high heterogeneity, which has determining economic incidences, should be detailed, via the accurate identification of the treatments used, their efficiency on the animals and their conditions of use.

One of the common denominators of organic farming, the extensiveness of the use of surfaces (from 15 to 30\% fewer animals per surface area than with conventional 
farming on similar zones), is a favourable factor for the control of parasitism (gastro-intestinal Strongyles). However, numerous other factors remain more or less to be considered by farmers, such as the determining effect of sanitation of the surfaces harbouring parasites by agronomic practices and adapted grazing strategy, with the privileged use of uncontaminated paddocks for the fattening of these animals.

\section{CONCLUSION}

Ovine sheepmeat production in France has been decreasing for the last two decades, due to the relatively low competitiveness as compared to other main productions. The large diversity of production systems and the environment in which they are used reveals a large adaptive capacity, illustrated by the variability of the observed zootechnical performances. On the contrary, it needs a lot of technical expertise, individual follow-up of the animals, and a globally high work load with quite often low worker profitability. The decrease in the French ovine population is even more harmful since sheep are herbivores that use and help develop low potential territories by keeping them open.

In the consumer's mind, sheep breeding represents a natural production, close to organic farming. Two principal elements can, however, modify the perception of the situation in organic farming: (1) the relatively high part of concentrates in the feed, in most systems and in particular in those that are out of season, (2) the control of sanitary problems, in particular the control of parasitism in young grassland lambs.

Several major questions are remaining about that subject, for organic farming systems:

- What are the efficiencies of several alternative phytotherapy products? Are they justified?
- What are the consequences of parasite infestation on final quality and production costs (growth retardation)?

- Can we define an acceptable level of animal parasitism?

Fattening of lambs indoors allows to avoid the parasitic problems. However, the economic incidence of the use of concentrates in the feed (low availability on the market and cost) which is fundamentally negative in organic farming, should lead to a maximal use of conserved fodder but even more so of grazing, caring about parasitic problems. Research is thus necessary to gain knowledge on the management and effect of parasites. One must also remember that one concern of conventional small ruminant farms is parasite resistance to antiparasitic drugs [10] and farmers will undoubtedly have to subscribe more and more to standards including regulations of the use of such products.

\section{ACKNOWLEDGEMENTS}

We would like to thank the farmers who lent us their technical and economic data, as well as the European Union for its financial support (Fonds Structurel Européen FEOGA 5b).

\section{REFERENCES}

[1] Agreste Conjoncture Productions Animales Ovins - Enquête 2000, SCEES (Service Central des Enquêtes et Études Statistiques), Direction des affaires financières, Ministère de l'Agriculture et de la Pêche France, 2, 2001.

[2] Benoit M., Laignel G., Liénard G., Facteurs techniques, cohérence de fonctionnement et rentabilité en élevage ovin allaitant. Exemples du Massif Central Nord et du Montmorillonnais, Rencontres Recherches Ruminants 6 (1999) 19-22.

[3] Benoit M., Laignel G., Liénard G., Rentabilité comparée des exploitations d'élevage ovins viande au travers du Réseau d'Information Comptable Agricole (RICA) 1998, Note pour Ministère de l'Agriculture, INRA, Laboratoire Économie de l'Elevage Theix, 2000, 10 p. 
[4] Brunet J., Le parasitisme des caprins dans l'Ardèche (1977-1978-1979), Bull. GTV 3 (1981) $58-66$

[5] Cabaret J., Bouilhol M., Mage C., Managing helminths of ruminants in organic farming, Vet. Res. 33 (2002) 625-640.

[6] Mage C., Bouilhol M., Archimbaud E., Jardin Y., Buscatto O., Parasitisme en production d'agneau d'herbe en agriculture biologique, Compte rendu No 9983220, Juillet 1998, Institut de l'Elevage, $33 \mathrm{p}$.

[7] Nicolas J.A, Dubost G., Quechon M., Enquête épidémiologique sur les parasites internes des ovins en Haute-Vienne, Rev. Méd. Vét. 135 (1984) 775-778.

[8] REPAB, Règlement Européen des Productions Animales Biologiques. Cahier des charges concernant le mode de production et de préparation des animaux et des produits animaux définissant les modalités d'application du règlement CEE No 2092/91 modifié du Conseil et/ou complétant les dispositions du règlement CEE No 2092/91 modifié du Conseil, Direction des politiques économique et internationale, Ministère de l'Agriculture et de la Pêche, France, 2000, $88 \mathrm{p}$

[9] Rey M., Mise en place de méthodes de surveillance du parasitisme interne des ovins dans le sud est de la France et prévision du risque d'infestation parasitaire, Thèse de doctorat vétérinaire, École Nationale Vétérinaire de Lyon, 1980, $81 \mathrm{p}$.

[10] Silvestre A., Leignel V., Berrag B., Gasnier N., Humbert J.-F., Chartier C., Cabaret J., Sheep and goat nematode resistance to anthelmintics: pro and cons among breeding management factors, Vet. Res. 33 (2002) 465-480.

[11] Thériez M., Aurousseau B., Prache S., Mendizabal J., Les défauts de couleur des gras d'agneaux, Rencontres Recherches Ruminants 4 (1997) 295-301.

[12] Van Wyk J.A., Bath G.F., The FAMACHA ${ }^{\odot}$ system for managing haemonchosis in sheep and goats by clinically identifying individual animals for treatment, Vet. Res. 33 (2002) 509-529. 